\title{
Conceptualizing the distinctiveness of team coaching
}

Article

Accepted Version

Jones, R., Napiersky, U. and Lyubovnikova, J. (2019)

Conceptualizing the distinctiveness of team coaching. Journal of Managerial Psychology, 34 (2). pp. 62-78. ISSN 0268-3946 doi: https://doi.org/10.1108/JMP-07-2018-0326 Available at https://centaur.reading.ac.uk/81560/

It is advisable to refer to the publisher's version if you intend to cite from the work. See Guidance on citing.

To link to this article DOI: http://dx.doi.org/10.1108/JMP-07-2018-0326

Publisher: Emerald

All outputs in CentAUR are protected by Intellectual Property Rights law, including copyright law. Copyright and IPR is retained by the creators or other copyright holders. Terms and conditions for use of this material are defined in the End User Agreement.

\section{www.reading.ac.uk/centaur}

\section{CentAUR}

Central Archive at the University of Reading

Reading's research outputs online 


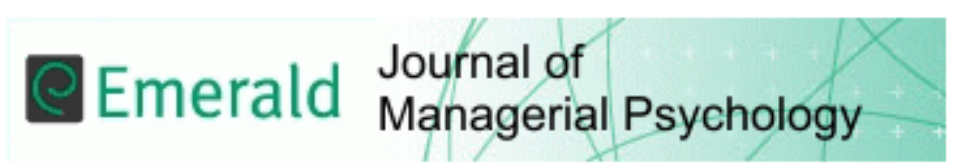

\section{CONCEPTUALIZING THE DISTINCTIVENESS OF TEAM COACHING}

\begin{tabular}{|r|l|}
\hline Journal: & Journal of Managerial Psychology \\
\hline Manuscript ID & JMP-07-2018-0326.R3 \\
\hline Manuscript Type: & Research Paper \\
\hline Keywords: & coaching, Teams, Training \\
\hline \multicolumn{2}{l}{} \\
\end{tabular}

SCHOLARONE"

Manuscripts 


\title{
CONCEPTUALIZING THE DISTINCTIVENESS OF TEAM COACHING
}

\author{
ABSTRACT \\ Purpose: \\ Team coaching (TC) is a popular new addition to the team learning and development \\ toolkit. However, the conceptualization of TC and the distinction between TC, team training, \\ team development and team building interventions remains unclear.

\section{Methodology:}

We address this significant gap by abductively exploring how TC is conceptualized in practice $(n=410)$. We survey practitioners engaged in delivering TC to ask how they would define TC and distinguish it from other team interventions.

\section{Findings:}

A thematic analysis of our data reveals eight themes, which can be used to define TC and illustrate areas of overlap and distinctiveness with other team interventions.

\section{Research/Practical Implications:}

The absence of a clearly defined construct is hindering the development of a rigorous theory of TC. The contribution of our paper is, therefore, a clear and comprehensive definition of TC, which can be used by researchers and practitioners alike when working within the domain of TC.

\section{Originality/Value:}

Our paper provides the first systematic exploration of a definition of TC in relation to alternative team interventions. By utilizing an abductive approach in our research, we are able to capitalize on practitioner experience in this practice-led field.

Key words: Team coaching; Team learning and development; Team performance 
Running Head: CONCEPTUALIZING THE DISTINCTIVENESS OF TC

\section{CONCEPTUALIZING THE DISTINCTIVENESS OF TEAM COACHING}

Teams are an integral element of effective organizations (Mathieu et al., 2017).

Consequently, learning and development needs have shifted from a sole focus on the individual to a focus on enabling the team as a whole to learn and develop in the context of its functions in order to enhance team effectiveness. A vast body of literature has developed examining the efficacy of a range of team-focused learning and development interventions (see Klein et al., 2009), the newest being team coaching (TC). TC has witnessed a surge in practice as evidenced by the recent rise in the publication of practitioner reports (WABC White Paper, 2016) and practitioner-oriented text-books (e.g., Hawkins, 2011).

Despite the increase in TC practice and practitioner-oriented literature, an empirically validated theory on TC is yet to emerge, and there is confusion regarding what TC actually is (Lawrence \& Whyte, 2017). This matter is further complicated by the somewhat overlapping nature of TC and other forms of team learning and development. The lack of clarity on the definition and conceptualization of TC is problematic for both theory development and empirical exploration (Kohler et al., 2017). Without an agreed upon, explicit definition which outlines underlying assumptions and boundaries of the concept, it is challenging if not impossible for the literature to develop further. Clear conceptualization is required to ensure that attention can be turned to the development and subsequent testing of a theory of effective TC which can begin to tell us if, how and why TC works. Such a conceptualization is also essential for enabling organizations to understand what exactly they are purchasing and why.

To address this issue, we adopt an abductive approach with an emic perspective and enable those who are currently practicing TC to derive and shape the development of an inclusive definition of TC. Since the literature lacks clarity, yet the intervention is being implemented in real-life, a logical next step is to ask those who are currently implementing 


\section{CONCEPTUALIZING THE DISTINCTIVENESS OF TC}

$\mathrm{TC}$ to provide their explanation of $\mathrm{TC}$, which can be integrated with the existing literature (Shepherd \& Suddaby, 2017). The key contribution of our paper is, therefore, a data driven definition of TC. This provides a clear departure from existing conceptualizations, which posits TC as a set of team leader behaviors (e.g., Hackman \& Wageman, 2005) and do not appear to reflect current practice. In turn, we clearly specify the boundaries of TC, including an explicit exploration of the similarities and differences of other team learning and development interventions, by synthesizing our data with the existing literature. In doing so, the literature can progress to the much-needed stage of rigorous theorizing and empirical testing, shifting the research agenda from defining TC to one which is focused on understanding the mechanisms through which TC can heighten team performance.

\section{Team Training, Team Building and Team Development}

The team learning and development literature generally focuses on three types of intervention: team training, team building and team development. Team training has been argued to be key to enhancing team effectiveness (Hughes et al., 2016) and targets latent teamwork knowledge, skills, and/or attitudinal competencies (KSAs) to improve performance (Salas \& Cannon-Bowers, 2001). Goldstein and Ford (2002) argued that team training methods are designed to enhance taskwork, teamwork and process improvement skills. Kozlowski and Ilgen (2006) provided clarification, defining team training as a systematic strategy that targets improvement in specific objectives or competencies designed to enhance teamwork.

Team building is a process intervention prompting team members to reflect on their behavior and interpersonal relations (Beer, 1980). Klein et al. (2009) argue that team building has suffered conceptualization issues in the past, however, a consensus appears to have been reached, with team building being defined as comprising four elements: goal-setting, interpersonal relations, role clarification and problem solving. Finally, team development is 


\section{CONCEPTUALIZING THE DISTINCTIVENESS OF TC}

an informal, holistic process that all team members go through together, by which group members attempt to create effective social structures and work process on their own (Kozlowski \& Ilgen, 2006). In their meta-analysis on team training effectiveness, Salas et al. (2008) coded studies on training content and differentiate between team training that focuses on taskwork, teamwork or a combination of both. According to Salas et al. (1992), team training interventions targeting taskwork KSAs, seek to develop technical competencies of team members and closely resemble Kozlowski and Ilgen's (2006) description of team training. In contrast, according to Salas et al. (1992), teamwork interventions are focused on improving how individuals work together effectively as a team. This definition closely resembles the definition of team building (Kozlowski \& Ilgen, 2006). Therefore, the key differentiator in the team learning and development literature appears to be the focus of development: whether that is on the task or the team (processes).

\section{Team Coaching}

A third of organizations report using TC (Lawrence \& Whyte, 2017), the popularity of TC as the newest team learning and development approach appears to be increasing. However, TC remains a poorly understood phenomena in terms of how it is defined and conceptualized and where the boundaries lie between TC and other team learning and development interventions (Lawrence \& Whyte, 2017). One particularly noteworthy contribution is the work of Hackman and Wageman (2005) who provide a theory of TC, defining it as 'direct interaction with a team intended to help members make coordinated and task appropriate use of their collective resources in accomplishing the team's work' (p.269). Hackman and Wageman (2005) position TC as an act of leadership, meaning that their theory predicts and explains the impact of coaching functions on team effectiveness when TC is provided by either the team leader or group members. However, it is consistently argued that coaching provided by an independent coach is conceptually different to coaching provided by 


\section{CONCEPTUALIZING THE DISTINCTIVENESS OF TC}

a supervisor or leader (Jones et al., 2016); primarily because the power relationship that exists between line managers and their subordinates is absent in the helping relationship between an independent coach and coachee. We suggest that Hackman and Wageman's (2005) theory of $\mathrm{TC}$ is not sufficiently inclusive for capturing the range of TC scenarios that occur in practice. Further, the model is yet to be empirically tested or validated. In the absence of any alternative models or frameworks on TC per se, the field of TC could, thus, be described as pre-theory.

\section{TABLE 1 HERE}

To examine the notion of TC, our review of the literature identified 15 different definitions published since 2000 (see Table 1), which we sought to appraise and evaluate in order to establish what has been accomplished in the field to date (Hodgkinson \& Ford, 2013). In order to synthesize the existing definitions in a systematic way, we utilized thematic analysis in order to identify the recurring patterns or themes across the existing definitions. Reviewing each definition separately, we identified the key words utilized within the definition. Table 1 includes details of the key words extracted from each theme. We then cross-referenced these key words and following the recommendation of Fugard and Potts (2015), sorted them into a hierarchical structure in order to group them into themes, as shown in Figure 1.

\section{FIGURE 1 HERE}

Representing the content identified in the definitions in this format, clearly illustrates the variation in the ways in which scholars have specified TC and helps explain why the current TC literature has been described as messy (Wotruba, 2016). Whilst the overall themes of the function or role of the coach, the outcomes from TC, the TC methods and the format of TC can be identified across many of the definitions, there is little agreement at the next level. For example, the role of the team coach is conceptualized in six different ways across the 15 


\section{CONCEPTUALIZING THE DISTINCTIVENESS OF TC}

definitions. The definitions also include contradictions such as coaching the team as a whole (Dassen, 2015; Hawkins, 2011) versus coaching individual team members (Diedrich, 2001) or no specification regarding either (Cardon, 2003; Clutterbuck, 2009; Skiffington \& Zeus, 2000). The range of content in the current definitions of TC also means that there is substantial overlap between many elements of the TC definitions shown in Table 1 and the definitions of team training, team building and team development discussed earlier. In Table 2, we summarize the key themes from the TC definitions and illustrate the overlap with other team learning and development interventions. Table 2 illustrates how the key themes explored in the extant TC literature specifying that TC involves problem-solving, raising awareness or use of reflection, a focus on teamwork, process, goals and objectives with a systematic approach are all elements that are also present in the definitions of at least one or sometimes more of the other forms of team learning and development interventions.

\section{TABLE 2 HERE}

When viewing the range of TC definitions in the context of other team learning and development definitions, it is clear that TC is yet to be concisely defined in a way that provides sufficient clarity, rigour and distinctiveness (Donaldson et al., 2013). Without this clear conceptualization of $\mathrm{TC}$, it is impossible to progress research onto more pertinent questions such as how and why TC works, or even if it works at all (Shepherd \& Suddaby, 2017).

In order to address these concerns, we adopt an abductive approach to our research with an emic perspective (Pike, 1966). Abduction can be described as the type of reasoning where the explanation of an event is provided from a theory on how the world works. This approach to research contrasts with the more widely utilized deductive and inductive approaches to theory development. Abductive theory development generates explanations for particular events based on a background theory of how the world works (Tavory \& Timmermans, 2014). Abductive reasoning is particularly useful as it provides a method of 


\section{CONCEPTUALIZING THE DISTINCTIVENESS OF TC}

explanation-based learning where an event or episode, not previously encountered, is explained on the basis of a theory about the relevant aspects of the world. That explanation is then generalized so that it will be useful in other situations. Arino et al. (2016) propose that abductive reasoning is an appropriate approach when researchers are seeking to discover something that is under specified theoretically, such as of the concept of TC. In particular, emic research (from the perspective of the participant), offers an alternative view to the existing literature by allowing us to discover the participants understanding of organizational situations. The TC context, being one which is practitioner rather than theory led, is an appropriate context for research of this nature as abduction assigns primacy to the empirical world where data can be gathered in the service of theorizing (Van Maanen et al., 2007). However, by adopting an abductive rather than inductive approach to our research, we acknowledge that whilst the domain of TC is underdeveloped theoretically, there is a background of literature, in particular when we consider the wider context of team learning and development, against which our abductions can be checked.

\section{METHOD}

\section{Participants and Procedures}

Accessing coaches with TC experience, our survey was shared by the main organizations with which coaches tend to be affiliated (listed alphabetically): Association for Coaching (AC); European Mentoring and Coaching Confederation (EMCC); International Coaching Community (ICC), the International Coach Federation (ICF) and the researchers' network. In total 410 participants completed our web-based survey. Participants ranged in age from 18 to $74($ mean age $=52.34, S D=8.93)$, were $51.6 \%$ female and $56.1 \%$ held a masters degree. A total of $69.6 \%$ of our sample worked as an external (versus an internal) coach and $79.1 \%$ held some form of coaching accreditation. The average number of years coaching experience was 11.24 years $(S D=7.00)$ and $\mathrm{TC}$ experience was 7.81 years $(S D=6.30)$. The 


\section{CONCEPTUALIZING THE DISTINCTIVENESS OF TC}

mean proportion of TC practice was $29.63 \%(S D=22.45)$. Participants reported coaching an average of 6.68 teams per annum $(S D=8.38)$ with the average size of the team coached being 9.24 individuals $(S D=4.36)$. The typical number of TC sessions per team was 1.62 sessions $(S D=.75)$ with the average sessions lasting an average of 157 minutes $(S D=$ 127.06). Data was collected between October 2016 and February 2017.

\section{Measures}

To address our research questions we asked participants three open-ended questions: 'How do you define TC?', 'How is TC different to one-to-one coaching?' and 'How is TC different to other team development interventions?' The survey was piloted with a small sample $(n=5)$, checking face and content validity. Questions were intentionally designed to be flexible and open-ended.

\section{Data Analysis}

Our data analysis was underpinned by a positivist approach (Arino et al., 2016). Based on this perspective, we analysed our participants' responses to our questionnaire as objective descriptions and, therefore, we did not seek to subjectively interpret our participants' responses to the questions. Responses were explicit, characterized by descriptive content written in a concise manner. Our analysis proceeded in two stages utilizing a thematic synthesis approach (Thomas \& Harden, 2008). Firstly, we adopted a double-blind approach to coding. The first two authors systematically reviewed participant responses and identified recurrent descriptive themes that appeared to be present in the data (Boyatzis, 1998). At stage two, the first two authors discussed the independently identified themes whereby similar themes were merged and themes, which did not frequently reoccur were deleted. Analysis continued with further iterations of discussion of themes and sub-themes with reference to the raw data, until a final set of themes were agreed. While it was not possible to calculate inter- 


\section{CONCEPTUALIZING THE DISTINCTIVENESS OF TC}

rater agreement, trustworthiness of our approach is reinforced by ensuring that all interpretations are supported by raw data (Kirrane et al., 2018).

\section{RESULTS}

Our results are structured around the three questions in our survey: 'How do you define TC?', 'How is TC different to one-to-one coaching?' and 'How is TC different to other team development interventions?'

\section{How Would You Define TC?}

Four themes were identified from our analysis: common goal; team performance; team learning and reflection; and TC activities.

\section{Common goal}

A recurrent response involved the assertion that a common goal was an essential component. Therefore, TC is focused on assisting a team achieve a common goal, purpose, objective or mission. For example:

"A facilitated process with a team of people - team in that they have a common purpose/goal and have to work inter-dependently to achieve that."

\section{Team performance}

Our second theme describes the output or outcome for a TC intervention; that is improved team performance. Therefore, TC enables individuals to perform effectively as a team. For example:

"To build a synergy among all team members so that result comes faster and create combined output more than the any individual."

\section{Team learning and reflection}

This theme turns to the process of how TC generates improvements in team performance. It describes $\mathrm{TC}$ as a dynamic collective process where team members learn from self-reflections and team member reflections. For example: 


\section{CONCEPTUALIZING THE DISTINCTIVENESS OF TC}

"Creating a small group reflective space in which participants learn from their own reflections and from the reflections of others guided by a coach."

A related sub-theme is the idea that during TC, team members will take on the role of coach themselves:

"each participant in TC will have to assume the coach's role, when someone else is

$$
\text { talking." }
$$

\section{TC activities}

Our final theme identified refers to the methodology, actions or process whereby a team coach improves the team's capability to achieve their shared goal and improve team performance. A range of TC activities were identified by participants including raising awareness:

"This is achieved by increasing interpersonal awareness within the team and extra organizational and environmental awareness"

Improving communication between team members:

"Providing teams opportunities to improve communication...."

"helping the team members to be more open to each other in order to get better

$$
\text { results" }
$$

As well as, building trusting relationships among team members:

"Creation of a space of trust and non judgment where each member of a team can truly express himself while the others truly listen."

\section{How is TC Different to One-to-One Coaching?}

Our analysis identified two themes: focus on the team as a system and advanced coaching skills.

\section{Focus on the team as a system}




\section{CONCEPTUALIZING THE DISTINCTIVENESS OF TC}

The first theme from this question describes how practitioners view the team of comprising of individuals, however these individuals form an interconnecting network which can be viewed as a complex whole. This complex whole is the focus of the TC:

"I consider the team as a system, a specific entity with its own needs and challenge"

"In TC, the coach focuses on the 'whole team' as one entity, as distinct from viewing it as a group of individuals."

\section{Advanced coaching skills}

The second theme leads on from the first. Coaching a group of individuals, all at the same time, is inherently more complex than coaching on a one-to-one basis. Our participants identified this as a core difference in the practice of TC compared to one-to-one coaching:

"Far more risky and complex. The difference between a solo recital and improvisational jazz with a group of musicians."

"It is far more complex because the group dynamic is constantly shifting - the coach's relationship is with the TEAM as an entity, yet it comprises individuals with their own aptitudes, attitudes, needs, ways of expressing their emotions and ideas."

A number of advanced skills were identified by participants as being required by coaches conducting TC. For example, the ability to listen to and take into account multiple perspectives:

"When working with several people at once the fundamental difference is that there are numerous thoughts and beliefs with which we have to work to achieve a common goal"

Ability to observe and interpret interactions:

"It is a question of "reading" the relationships between members and how that network interferes with or encourages the achievement of result."

The team coach needs to have a grasp of team facilitation techniques: 


\section{CONCEPTUALIZING THE DISTINCTIVENESS OF TC}

"This means that the team coach needs to understand and be skilled in group/team processes, dynamics and facilitation.”

Additionally, the challenge of building trust within the TC sessions to enable effective openness and sharing for reflective learning:

"You also have to create a strong sense of safety since you are inviting people to "get real" with folks they work with regularly - something that can feel threatening to some

$$
\text { people." }
$$

\section{How is TC Different to Other Team Development Interventions?}

Our analysis identified two themes: coaching techniques and longer-term.

\section{Coaching techniques}

When clarifying the difference between TC and team development interventions, the key difference specified by participants was that TC involved the application of traditional coaching techniques to achieve the desired outcomes. Therefore, whilst the outcomes from TC and other types of team development interventions may be the same, the process by which these outcomes are achieved are likely to be different. For example, a core component of coaching is the use of dialogue and conversation and, in particular, effective questioning to encourage reflection:

"It is a focused collective conversation that is geared to increase insights and action around issues of importance for the people that we are working with."

Other participants highlighted that the coach is not an expert and does not provide instruction, training or guidance.

\section{Longer-term}

Finally, participants identified that when compared to other forms of team development, TC is a longer-term intervention. For example: "coaching is an on-going process rather than an isolated intervention" 


\section{CONCEPTUALIZING THE DISTINCTIVENESS OF TC}

"TC is more in-depth, a process with defined agenda and outcomes. It's a learning process that taps into the wisdom of the team, which has all the answers. Team development interventions are rather pointed, single events."

\section{DISCUSSION}

This paper addressed two research questions. Firstly, how is TC defined and secondly, how is TC different from other forms of team learning and development? Our aim was to generate a new conceptualization of TC that would provide much-needed clarity and distinctiveness to the field.

The analysis of TC practitioners' definitions and views on distinctiveness identified a number of key themes that contribute to the conceptualization of TC. We summarize these themes in Table 3 and illustrate how they align with the existing TC definitions and the definitions of team training, team building and team development. Table 3 shows that the themes of common team goal, improving team performance, encouraging team learning and reflection and TC activities such as building trusting relationships, reflect the existing definitions from the TC literature. However, these are also the themes that have the highest degree of overlap with other forms of team learning and development.

\section{TABLE 3 HERE}

Herein is where the issue lies with the current definitions of TC; they do not go far enough to distinguish what the differences are between TC and other forms of team learning and development. Our analysis extends these definitions by providing further clarity on how TC is distinct, namely the themes: advanced coaching skills (such as simultaneously understanding multiple perspectives; observing and interpreting interactions), application of coaching techniques (such as questioning and abstaining from advice giving) and the longerterm nature of TC. These themes also do not appear in the existing TC definitions, and thus provide our newly derived definition with a clear departure from the literature to date. 


\section{CONCEPTUALIZING THE DISTINCTIVENESS OF TC}

Additionally, the focus of TC on the team as a system is particularly important in the context of some of the existing definitions of TC. Whilst we agree that TC may involve an element of coaching of individual team members on a one-to-one basis, fundamental to TC is the coaching of all members as a team (i.e. collectively). In this sense, our conceptualization differs from the existing definitions that either do not explicitly state whether TC must involve coaching of the whole team collectively (i.e. Cardon, 2003) or imply that TC can be provided to team members on a one-to-one basis (i.e. Britton, 2015). In Table 4, we further clarify the classification of team learning and development interventions as either team training, team development, team building or TC. The distinguishing factor here, particularly between team building and TC which are the most similar, is that TC is longer-term compared to team building. Further, TC achieves team goals and improvement in team performance through the application of coaching techniques.

\section{TABLE 4 HERE}

Subsequently, based on the analysis presented in this paper, we propose the following definition of TC:

Team coaching is a team-based learning and development intervention that considers the team to be a system and is applied collectively to the team as a whole. The focus of team coaching is on team performance and the achievement of a common or shared team goal. Team learning is empowered via specific team coaching activities for self and team reflection, which are facilitated by the team coach(es) through the application of coaching techniques such as impactful, reflective questioning which raises awareness, builds trusting relationships and improves communication. A team coach does not provide advice or solutions to the team. Rather, team coaching requires advanced coaching skills from the coach such as considering multiple perspectives 
CONCEPTUALIZING THE DISTINCTIVENESS OF TC

simultaneously and observing and interpreting dynamic interactions and is

typically provided over a series of sessions rather than as a one-off intervention.

To further illustrate our definition of TC, in Table 4, we provide specific, work-based examples of TC, team training, team development and team building. To aid practical application, we also provide an example of a specific situation where it would be appropriate to utilize TC as defined here and explain why this example would fall outside the remit of the alternative team development interventions.

Consider a senior management team in which it has become apparent that team members do not openly discuss important issues or share key information in meetings. Instead, conversations are typically kept at a superficial level, focusing on the transactional processes of 'getting the job done' sufficiently. 'Real' conversations regarding the underlying relational issues in the team and how these impact performance, take place in hallways and behind closed doors. A complex, sensitive situation such as this is best suited to be tackled with TC, rather than the other aforementioned interventions, for a number of reasons.

Firstly, team training is unlikely to adequately tackle the interpersonal nature of the issue given that the focus of team training tends to concern taskwork and the specific KSAs needed to complete the job. Upskilling team members through team training may enhance the capabilities of the team, but the underlying interpersonal issues will remain untapped. Secondly, team development is a more informal intervention that is focused on developing teamwork and the relationships between the team members. It generally involves a short-term or a one-off event, taking the team out of their normal work context to work on a unique problem together, for example. However, one-off event such as this is unlikely to sufficiently probe into the existing issues that are limiting the teams capacity to communicate openly and honestly with 


\section{CONCEPTUALIZING THE DISTINCTIVENESS OF TC}

one another in team meetings. Finally, team building also tends to be a formal, one-off, or short-term event, which would similarly prevent the team from properly reflecting on its functioning and composition and to constructively identify underlying causes of problems.

Conversely, TC would enable the team to work with a team coach over a sustained period, to carefully unpick its problems, reflect on its performance and refocus on its common goal, empowering team members to learn from deeper individual and collective reflections. The team coach would utilize advanced questioning skills, facilitate reflective learning and address fundamental issues associated with trust and communication. By considering the multiple perspectives of team members simultaneously and observing and interpreting dynamic interactions, the team coach is able to raise the teams awareness of these issues in order for the team to effectively tackle its issues. TC would aim to create a shift in the team's way of working together, facilitating a sustainable change.

Our definition of TC can also be distinguished from definitions of one-to-one coaching. For example, Hall et al. (1999) define coaching as 'a practical, goal-focused form of personal one-to-one learning for busy executives. Whilst Rogers (2012) defines coaching as 'a partnership of equals whose aim is to achieve speedy, increased and sustainable effectiveness through focused learning. Coaching raises self-awareness, identifies choices and has the sole aim of closing the gaps between potential and performance' (p.7). While all of the definitions refer to the intervention as being focused on learning and development, all refer to the relationship as an important element of the intervention, all definitions include reference to goals and the role of raising awareness or reflection, a key departure lies in the actors. The one-to-one coaching definitions are solely focused at the individual level whereas our TC definition refers to the group level and explicitly captures the distinct dynamic nature 


\section{CONCEPTUALIZING THE DISTINCTIVENESS OF TC}

of TC, as well as the inherent complexities of simultaneously managing individual perspectives and intra-team dynamics in the coaching process. Further, in our definition, the vehicle for change is collective learning, with the desired outcome being team (rather than individual) performance.

\section{Implications and Application}

The previously ill-defined nature of TC meant that it was difficult for organizations to know what to expect when they employ a team coach and understand when TC is appropriate compared to other forms of intervention. Our findings have helped to shed some light on these issues. For example, TC is likely to be appropriate when the focus of the learning and development is on teamwork processes rather than team taskwork. Furthermore, TC requires the whole team to be present and is likely to be of a longer duration than a one-off event. Our research highlights the complexity of TC and whilst providing specific recommendations regarding the matching the team coach to the team is beyond the scope of our paper, we suggest that organizations should carefully consider the knowledge, skills and expertise of team coaches to ensure that they have the requisite ability to simultaneously manage multiple perspectives; observe and interpret interactions; build trust to enable openness and sharing and have knowledge of team facilitation techniques.

\section{Future Research}

There are a number of interesting avenues for future TC theorizing and research. Firstly, our research has highlighted that TC requires advanced coaching skills. Research could seek to explore these skills and specifically identify the key competencies required for TC. A field study focused on developing deeper understanding of team coach competencies would enable organizations to effectively assess potential team coaches and further inform TC educators regarding the essential elements of team coach training programmes. Important elements of the TC process such as raising awareness through effective questioning, 


\section{CONCEPTUALIZING THE DISTINCTIVENESS OF TC}

improving communication and building trusting relationships could also be addressed in future research, through the use of observational studies, for example. Our paper also provides the conceptual foundation for the development of a quantitative measure of TC. Such a follow-up quantitative study could specifically examine the incremental predictive validity of TC over and above other team-targeted interventions.

Our research identified an intriguing discrepancy between the qualitative results, where participants indicated their view that TC is a longer-term intervention, yet the demographic data reported showed that an average of only 1.6 coaching sessions were conducted per team, with an average session duration of around 2.5 hours. We postulate that this discrepancy may be highlighting a misalignment between team coaches view of the preferred duration of TC to create desired results (i.e. longer term) and the reality of what organizations may be prepared to pay for. Future research should seek to explore this finding further, particularly from the perspective of the TC procurer.

Finally, by providing a clear and comprehensive definition of TC the next important step in the TC conversation is the development of a comprehensive theory of TC, providing a series of testable propositions that can further guide future research on TC effectiveness.

\section{CONCLUSION}

There has been a recent growth in the popularity and practice of TC. Consequently, research in this field is likely to generate a significant impact in terms of informing best practice in the application of TC. Despite this, there has been a lack of clear conceptualization of TC which has significantly impaired the development of a rigorous theory of TC. Our paper has addressed some of these significant gaps by surveying practitioners involved in the delivery of TC to understand their perspective on this growing methodology in team learning and development. Our findings, when explored in the context of definitions of other team learning and development interventions and the existing TC 


\section{CONCEPTUALIZING THE DISTINCTIVENESS OF TC}

definitions, have provided greater clarity to the factors that make TC distinct. It is our hope that this paper will stimulate future research that will provide a focused examination into the efficacy of TC. 


\section{CONCEPTUALIZING THE DISTINCTIVENESS OF TC}

\section{REFERENCES}

Arino, A., LeBaron, C., \& Milliken, F. J. (2016). Publishing qualitative research in academy of management discoveries. Academy of Management Discoveries, 2, 109-113

Beer, M. (1980). Organization change and development: A systems view. Glenview, IL: Scott, Foresman \& Co

Boyatzis, R. E. (1998). Transforming qualitative information: Thematic analysis and code development. California: Sage

Brennan, D. \& Hellbom, K. (2016). Positive team coaching. Industrial and Commercial Training, 48, 333-337. doi: 10.1108/ICT-01-2016-0007

Britton, J. (2015). Expanding the coaching conversation: group and team coaching. Industrial and Commercial Training, 47, 116-120. doi: 10.1108/ICT-10-2014-0070

Bryman, A. (2004). Social Research Methods. Oxford, UK: Oxford University Press

Cardon, A. (2003). Le coaching d'equipes [Team coachingTC]. Paris, France: Ed. d'Organisation

Clutterbuck, D. (2009). Coaching teams in the workplace. EFMD Global Focus, 3, 914

Dassen, M. (2015). Drama Techniques in Team Coaching. International Journal of Evidence Based Coaching and Mentoring, 13, 43-57

DiazGranados, D., Shuffler, M.L., Wingate, J.A., \& Salas, E. (2017). Team Development Interventions. In E. Salas, R. Rico, \& J. Passmore (Eds.), The Psychology of Team Working and Collaborative Processes (pp.555-586) Chichester: John Wiley \& Sons Ltd

Diedrich, R. (2001). Lessons Learned in - and Guidelines for - Coaching Executive Teams. Consulting Psychology Journal: Practice and Research, 53, 238-239.

doi/10.1037/1061-4087.53.4.238 
CONCEPTUALIZING THE DISTINCTIVENESS OF TC

Dimas, I., Rebelo, T., \& Lourenço, P. (2016). Team coaching: One more clue for fostering team effectiveness. Revue Européenne de Psychologie Appliquée/European Review of Applied Psychology, 66, 233-242. doi.org/10.1016/j.erap.2016.05.003

Donaldson, L., Qiu, J., \& Luo, B. N. (2013). For rigour in organizational management theory research. Journal of Management Studies, 50, 153-172

Dunlop, H. (2006). An Exploratory Investigation into the Perceived Effects of Team Coaching in the Construction Sector. The International Journal of Mentoring and Coaching, IV, 2, 24-44

Fugard, A. J. B., \& Potts, H. W. W. (2015). Supporting thinking on sample sizes for thematic analyses: a quantitative tool. International Journal of Social Research Methodology, 18, 669-684. doi: 10.1080/13645579.2015.1005453

Goldstein, I. L., \& Ford, J. K. (2002). Training in organizations: Needs assessment, development, and evaluation, $4^{\text {th }}$ Ed. Belmont, CA: Wadsworth Publishing Co Ltd

Giffard, M., \& Moral, M. (2015). Coaching d'équipe-3e édition: Outils et pratiques. Paris: Armand Colin

Hackman, J. R., \& Wageman, R. (2005). A theory of team coaching. Academy of Management Review, 30, 269-287. doi: 10.5465/AMR.2005.16387885

Hall, D. T., Otazo, K. L., \& Hollenbeck, G. P. (1999). Behind closed doors: What really happens in executive coaching. Organizational Dynamics, 27, 39-53. doi: $10.1016 / \mathrm{S} 0090-2616(99) 90020-7$

Hawkins, P. (2011). Leadership Team Coaching: Developing collective transformational leadership. London: Kogan Page

Hodgkinson, G. P., \& Ford, J. K. (2013). Change and continuity in the advancement of (scholarly) knowledge and its dissemination. Journal of Organizational Behavior, 34(S1), S1-S6. doi: 10.1002/job.1895 


\section{CONCEPTUALIZING THE DISTINCTIVENESS OF TC}

Hughes, A.M., Gregory, M. E., Joseph, D. L., Sonesh, S. C., Marlow, S. L., Lacerenza, C. N., \& Salas, E. (2016). Saving lives: A meta-analysis of team training in healthcare. Journal of Applied Psychology, 101, 1266-1304. doi: 10.1037/ap10000120

Jones, R. J., Woods, S. A., \& Guillaume, Y. R. F. (2016). The effectiveness of workplace coaching: A meta-analysis of learning and performance outcomes from coaching. Journal of Occupational and Organizational Psychology, 89, 249-277. doi:

10.1111/joop.12119

Kirrane, M., Breen, M., \& O'Connor, C. (2018). A qualitative investigation of the origins of excessive work behaviour. Journal of Occupational and Organizational Psychology, 91, 235-260. doi: 10.1111/joop.12203

Klein, C., DiazGranados, D., Salas, E., Le, H., Burke, C. S., Lyons, R., \& Goodwin, G. F. (2009). Does team building work? Small Group Research, 40, 181-222. doi: $10.1177 / 1046496408328821$

Kohler, T., Landis, R. S., \& Cortina, J. M. (2017). Establishing Methodological Rigor in Quantitative Management Learning and Education Research: The Role of Design, Statistical Methods, and Reporting Standards. Academy of Management Learning \& Education, 16, 173-192. doi: 10.5465/amle.2017.0079

Kozlowski, S. W. J., \& Ilgen, D. R. (2006). Enhancing the effectiveness of work groups and teams. Psychological Science in the Public Interest, 7, 77-124. doi: 10.1111/j.1529-1006.2006.00030.x

Lawrence, P., \& Whyte, A. (2017). What do experienced team coaches do? Current practice in Australia and New Zealand. International Journal of Evidence Based Coaching and Mentoring, 15, 94-113 
CONCEPTUALIZING THE DISTINCTIVENESS OF TC

Mathieu, J. E., Hollenbeck, J. R., van Knippenberg, D., \& Ilgen, D. R. (2017). A century of work teams in the Journal of Applied Psychology. Journal of Applied Psychology, 102, 452-467. doi: :10.1037/ap10000128

Peters, J., \& Carr, C. (2013). Team effectiveness and team coaching literature review. Coaching: An International Journal of Theory, Research and Practice, 2, 116-136. doi: $10.1080 / 17521882.2013 .798669$

Pike, K. (1966). Etic and emic standpoints for the description of behavior. In A. G. Smith (Ed.), Communication and culture: Readings in the codes of human interaction (pp.152-163). New York, NY: Holt, Rinehart \& Winston

Rogers, J. (2012). Coaching Skills: A Handbook, Third Edition, Maidenhead: Open University Press

Salas, E., \& Cannon-Bowers, J. A. (2001). The science of training: A decade of progress. Annual review of psychology, 52, 471-499. doi: 10.1146/annurev.psych.52.1.471

Salas, E., DiazGranados, D., Klein, C., Burke, C. S., Stagl, K. C., Goodwin, G. F., \& Halpin, S. M. (2008). Does team training improve team performance? A metaanalysis. Human factors, 50, 903-933. doi: 10.1518/001872008X375009

Salas, E., Dickinson, T.L., Converse, S.A., \& Tannenbaum, S.I. (1992). Toward an understanding of team performance and training. In R.W. Swezey \& E. Salas (Eds.), Teams: Their training and performance (pp.3-29). Norwood, NJ: Ablex

Shepherd, D. A., \& Suddaby, R. (2017). Theory building: A review and integration. Journal of Management, 43, 59-86

Skiffington, S., \& Zeus, P. (2000). The complete guide to coaching at work. New York: McGraw-Hill

Tavory, I., \& Timmermans, S. (2014). Abductive analysis: Theorizing qualitative research. London: The University of Chicago Press 


\section{CONCEPTUALIZING THE DISTINCTIVENESS OF TC}

Thomas, J., \& Harden, A. (2008). Methods for the thematic synthesis of qualitative research in systematic reviews. BMC medical research methodology, 8,45 . doi:

$10.1186 / 1471-2288-8-45$

Thornton, C. (2010). Group and team coaching: The essential guide. New York: Routledge

Van Maanen, J., Sørensen, J. B., \& Mitchell, T. R. (2007). The interplay between theory and method. Academy of Management Review, 32, 1145-1154

Worldwide Association of Business Coaches (2016). Team coaching: Why, where, when \& How. Accessed from: http://www.wabccoaches.com/white papers/index.html on 17th January 2017.

Wotruba, S. (2016). Leadership Team Coaching; a trust-based coaching relationship. International Journal of Evidence Based Coaching and Mentoring, 10, 98-109 
TEAM COACHING

TABLES

Table 1

Definitions of team coaching from the team coaching literature

\begin{tabular}{|c|c|c|c|}
\hline Author & Date & Definition & $\begin{array}{l}\text { Key Words Identified } \\
\text { in Thematic Analysis }\end{array}$ \\
\hline $\begin{array}{l}\text { Brennan \& } \\
\text { Hellbom }\end{array}$ & 2016 & $\begin{array}{l}\text { Team coaching is about eliciting the } \\
\text { wisdom, strength, learning and } \\
\text { commitment from the team. }\end{array}$ & $\begin{array}{l}\text { Learning } \\
\text { Commitment }\end{array}$ \\
\hline Britton & 2015 & $\begin{array}{l}\text { A sustained series of conversations [...] } \\
\text { The focus is on goal setting, deepening } \\
\text { awareness, supporting action and } \\
\text { creating accountability. The focus of the } \\
\text { coaching may be on the team as a } \\
\text { system and/or strengthening individuals } \\
\text { in the team. Team coaching links back to } \\
\text { business goals focusing on results and } \\
\text { relationships }\end{array}$ & $\begin{array}{l}\text { Conversation } \\
\text { Goal setting } \\
\text { Awareness (raise } \\
\text { awareness/reflective } \\
\text { capability) } \\
\text { Supporting } \\
\text { (helping/supporting) } \\
\text { Accountability } \\
\text { Team as a system } \\
\text { (focus on system) } \\
\text { Individuals in the team } \\
\text { (team \& individuals } \\
\text { coached) } \\
\text { Relationships (enhance } \\
\text { relationships) }\end{array}$ \\
\hline Cardon & 2003 & $\begin{array}{l}\text { Its aim is to accompany the development } \\
\text { of the collective performance of a team, } \\
\text { in such a way that it can be monitored } \\
\text { and measured, so that the operational } \\
\text { result of the whole outweighs by far the } \\
\text { potential of the sum of its members. It } \\
\text { aims at supporting a team in the } \\
\text { discovery, definition and optimisation of } \\
\text { its collective processes and operational } \\
\text { modes using methods of collective } \\
\text { analysis and diagnosis. }\end{array}$ & $\begin{array}{l}\text { Collective performance } \\
\text { Monitored } \\
\text { (monitoring) } \\
\text { Support } \\
\text { (helping/supporting) } \\
\text { Analysis and diagnosis }\end{array}$ \\
\hline Clutterbuck & 2009 & $\begin{array}{l}\text { A learning intervention designed to } \\
\text { increase collective capability and } \\
\text { performance of a group or team, through } \\
\text { application of the coaching principles of } \\
\text { assisted reflection, analysis and } \\
\text { motivation for change }\end{array}$ & $\begin{array}{l}\text { Collective performance } \\
\text { Reflection (raise } \\
\text { awareness/reflective } \\
\text { capability) } \\
\text { Motivation }\end{array}$ \\
\hline Dassen & 2015 & $\begin{array}{l}\text { Teams-as-a-whole as the object of } \\
\text { coaching, primarily aimed at increasing } \\
\text { performance, learning capability and } \\
\text { dynamics of the group as a whole, with }\end{array}$ & $\begin{array}{l}\text { Team-as-a-whole } \\
\text { (whole team coached } \\
\text { only) } \\
\text { Performance }\end{array}$ \\
\hline
\end{tabular}




\begin{tabular}{|c|c|c|c|}
\hline Author & Date & Definition & $\begin{array}{l}\text { Key Words Identified } \\
\text { in Thematic Analysis }\end{array}$ \\
\hline & & $\begin{array}{l}\text { possible benefits in terms of learning } \\
\text { and increased performance and well- } \\
\text { being for individual and team members. }\end{array}$ & $\begin{array}{l}\text { (collective } \\
\text { performance) } \\
\text { Learning }\end{array}$ \\
\hline $\begin{array}{l}\text { DiazGranados } \\
\text { et al. }\end{array}$ & 2017 & $\begin{array}{l}\text { Team coaching is a process to help the } \\
\text { team identify their unique team dynamic } \\
\text { by demonstrating gaps in perception and } \\
\text { thinking, and creating a shared group } \\
\text { understanding }\end{array}$ & $\begin{array}{l}\text { Help } \\
\text { (helping/supporting) } \\
\text { Gaps in perception } \\
\text { (raise } \\
\text { awareness/reflective } \\
\text { capability) }\end{array}$ \\
\hline Diedrich & 2001 & $\begin{array}{l}\text { The coaching of a team is a process } \\
\text { where the consulting psychologist has an } \\
\text { ongoing, helping relationship with both } \\
\text { the team and the individual executives; } \\
\text { [...]. Coaching a team is an iterative } \\
\text { process for both the team and the } \\
\text { individual that is developmentally } \\
\text { orientated as opposed to being a } \\
\text { problem-centred quick fix for the team }\end{array}$ & $\begin{array}{l}\text { Ongoing } \\
\text { (ongoing/iterative) } \\
\text { Helping } \\
\text { (helping/supporting) } \\
\text { Both the team and the } \\
\text { individual (team \& } \\
\text { individual coached) } \\
\text { Iterative } \\
\text { (ongoing/iterative) }\end{array}$ \\
\hline $\begin{array}{l}\text { Dimas, } \\
\text { Rebelo \& } \\
\text { Lourenço }\end{array}$ & 2016 & $\begin{array}{l}\text { Team coaching can be defined as an } \\
\text { interaction between a coach and a team, } \\
\text { in order to reflect upon, define and } \\
\text { implement new strategies to achieve } \\
\text { team purposes. }\end{array}$ & $\begin{array}{l}\text { Reflect (raise } \\
\text { awareness/reflective } \\
\text { capability) } \\
\text { Define and implement } \\
\text { new strategies }\end{array}$ \\
\hline Dunlop & 2006 & $\begin{array}{l}\text { Enabling changes in individual and team } \\
\text { thinking and behaviour within and } \\
\text { outside the immediate team. An } \\
\text { independent coach helps teams to } \\
\text { explore their coaching goals through } \\
\text { raising their level of awareness, } \\
\text { challenging their thinking and } \\
\text { assumptions, helping them to reflect and } \\
\text { develop their own solutions. }\end{array}$ & $\begin{array}{l}\text { Independent coach } \\
\text { (coach independent to } \\
\text { the team) } \\
\text { Helps } \\
\text { (helping/supporting) } \\
\text { Goals (goal-setting) } \\
\text { Raising their level of } \\
\text { awareness (raise } \\
\text { awareness/reflective } \\
\text { capability) } \\
\text { Challenging } \\
\text { Reflect (raise } \\
\text { awareness/reflective } \\
\text { capability) } \\
\text { Develop their own } \\
\text { solutions (problem- } \\
\text { solving as a cognitive } \\
\text { outcome) }\end{array}$ \\
\hline $\begin{array}{l}\text { Giffard \& } \\
\text { Moral }\end{array}$ & 2015 & $\begin{array}{l}{[\ldots] \text {, coaching a team is about guiding it }} \\
\text { so that the team finds and proposes by } \\
\text { itself its own answers to the questions it } \\
\text { is wondering about or to the challenges } \\
\text { and problems that it faces. The team }\end{array}$ & $\begin{array}{l}\text { Guiding } \\
\text { Finds and proposes by } \\
\text { itself its own answers } \\
\text { to the questions } \\
\text { (problem-solving as a }\end{array}$ \\
\hline
\end{tabular}


TEAM COACHING

\begin{tabular}{|c|c|c|c|}
\hline Author & Date & Definition & $\begin{array}{l}\text { Key Words Identified } \\
\text { in Thematic Analysis }\end{array}$ \\
\hline & & $\begin{array}{l}\text { coach is the mirror which enables the } \\
\text { team to see its own system of } \\
\text { representation, to identify the strengths } \\
\text { and dysfunctions in its perception of the } \\
\text { reality to make its processes evolved } \\
\text { and, more generally to invent its own } \\
\text { solutions. }\end{array}$ & $\begin{array}{l}\text { cognitive outcome) } \\
\text { See its own system } \\
\text { (focus on system) } \\
\text { Identify strengths and } \\
\text { dysfunctions (raise } \\
\text { awareness/reflective } \\
\text { capability) }\end{array}$ \\
\hline $\begin{array}{l}\text { Hackman \& } \\
\text { Wageman }\end{array}$ & 2005 & $\begin{array}{l}\text { Direct interaction with a team intended } \\
\text { to help members in the co-ordinated and } \\
\text { task-appropriate use of their collective } \\
\text { resources in accomplishing the team's } \\
\text { work }\end{array}$ & $\begin{array}{l}\text { Direct interaction with } \\
\text { a team (whole team } \\
\text { coached only) } \\
\text { Help } \\
\text { (helping/supporting) } \\
\text { Co-ordinated (co- } \\
\text { ordinating) }\end{array}$ \\
\hline Hawkins & 2011 & $\begin{array}{l}\text { A process, by which a team coach works } \\
\text { with a whole team, }[\ldots] \text {, in order to help } \\
\text { them improve their collective } \\
\text { performance and how they work } \\
\text { together, and also how they develop } \\
\text { their collective leadership to more } \\
\text { effectively engage with all their key } \\
\text { stakeholder groups to jointly transform } \\
\text { the wider business }\end{array}$ & $\begin{array}{l}\text { With a whole team } \\
\text { (whole team coached } \\
\text { only) } \\
\text { Help } \\
\text { (helping/supporting) } \\
\text { Collective performance } \\
\text { Collective leadership }\end{array}$ \\
\hline Peters \& Carr & 2013 & $\begin{array}{l}\text { Team coaching is a comprehensive and } \\
\text { systemic approach to support a team to } \\
\text { maximise their collective talent and } \\
\text { resources to effectively accomplish the } \\
\text { work of the team. }\end{array}$ & $\begin{array}{l}\text { Systemic (focus on } \\
\text { system) } \\
\text { Support } \\
\text { (helping/supporting) }\end{array}$ \\
\hline $\begin{array}{l}\text { Skiffington \& } \\
\text { Zeus }\end{array}$ & 2000 & $\begin{array}{l}\text { Facilitating problem solving and conflict } \\
\text { management, monitoring team } \\
\text { performance and co-ordinating between } \\
\text { the team and a more senior management } \\
\text { sponsor }\end{array}$ & $\begin{array}{l}\text { Facilitating } \\
\text { Problem-solving } \\
\text { (problem-solving as a } \\
\text { cognitive outcome) } \\
\text { Conflict management } \\
\text { Monitoring } \\
\text { Team performance } \\
\text { (collective } \\
\text { performance) } \\
\text { Co-ordinating }\end{array}$ \\
\hline Thornton & 2010 & $\begin{array}{l}\text { The coaching of a team towards the } \\
\text { achievement of collective goals, as a } \\
\text { vehicle for delivering additional value } \\
\text { through the creation of high-performing } \\
\text { teams }\end{array}$ & Goals (goal-setting) \\
\hline
\end{tabular}

Note: The terms in italics within parentheses in the 'Key words identified in the thematic analysis' column donates the term used to classify this key word in Figure 1. For all other key words, the exact terminology has been used in Figure 1. 
TEAM COACHING

Table 2

Summary of team coaching definitions and comparison with other team learning and development interventions.

\begin{tabular}{ll}
\hline Element & Intervention \\
\hline Problem-solving & Team coaching (Skiffington \& Zeus, 2000); Team \\
& building (Klein et al., 2009) \\
\hline Raising awareness/reflection & Team coaching (Britton, 2015; Clutterbuck, 2009; \\
& Dimas, Rebelo \& Lourenco, 2016; DiazGranados et al., \\
& 2017; Dunlop, 2006; Giffard \& Moral, 2015); \\
& Team building (Beer, 1980) \\
\hline Process focus (teamwork) & Team coaching (Cardon, 2003; Giffard \& Moral, 2015; \\
& Hawkins, 2011); \\
& Team building (Beer, 1980; Klein et al., 2009); Team \\
& development (Kozlowski \& Ilgen, 2006) \\
\hline Goal/objective focused & Team coaching (Peters \& Carr, 2013); \\
& Team training (Kozlowski \& Ilgen, 2006) \\
\hline Systematic approach & Team coaching (Britton, 2015; Cardon, 2003; Dunlop, \\
\hline & \\
& \\
&
\end{tabular}


TEAM COACHING

\section{Table 3}

\section{Comparison of our team coaching themes with definitions of team training, team building, team development and other team}

coaching definitions

\begin{tabular}{|c|c|c|c|}
\hline Theme & 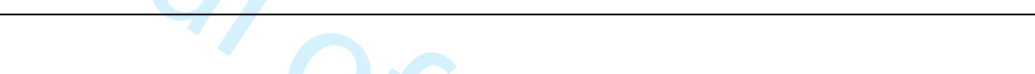 & Team interventions & Team coaching definitions \\
\hline Common team goal & $\begin{array}{l}\text { Team coaching is focused on achieving a common or shared } \\
\text { goal }\end{array}$ & $\begin{array}{l}\text { Team training (Kozlowski } \\
\text { \& Ilgen, 2006) } \\
\text { Team building (Klein et al. } \\
2009 \text { ) }\end{array}$ & $\begin{array}{l}\text { Britton, 2013; Cardon, 2003; } \\
\text { Dunlop, 2006; Thornton, } \\
2010\end{array}$ \\
\hline $\begin{array}{l}\text { Focus on team } \\
\text { performance }\end{array}$ & $\begin{array}{l}\text { The desired output or outcome of team coaching is improved } \\
\text { team performance }\end{array}$ & $\begin{array}{l}\text { Team training (Salas \& } \\
\text { Cannon-Bowers, 1997; } \\
2000 \text { ) }\end{array}$ & $\begin{array}{l}\text { Cardon, 2003; Clutterbuck, } \\
\text { 2009; Dassen, 2015; } \\
\text { Hawkins, 2011; Skiffington } \\
\text { \& Zeus, 2000; Thornton, } \\
2010\end{array}$ \\
\hline $\begin{array}{l}\text { Team learning \& } \\
\text { reflection }\end{array}$ & $\begin{array}{l}\text { Team coaching achieves team learning via self and team } \\
\text { member reflections }\end{array}$ & Team building (Beer, 1980) & $\begin{array}{l}\text { Britton, 2013; Clutterbuck, } \\
\text { 2009; Dimas et al., 2016; }\end{array}$ \\
\hline
\end{tabular}




\begin{tabular}{|c|c|c|c|}
\hline & & & $\begin{array}{l}\text { DiazGranados et al., 2017; } \\
\text { Dunlop, 2006; Giffard \& } \\
\text { Moral, } 2015\end{array}$ \\
\hline $\begin{array}{l}\text { Team coaching } \\
\text { activities }\end{array}$ & $\begin{array}{l}\text { The methodology, actions or processes whereby a team coach } \\
\text { enables improvement in the teams' capability to achieve their } \\
\text { shared goal and improve team performance. Includes raising } \\
\text { awareness, improving communication and building trusting } \\
\text { relationships. }\end{array}$ & $\begin{array}{l}\text { Team building (Beer, 1980) } \\
\text { Team development } \\
\text { (Kozlowski \& Ilgen, 2006) }\end{array}$ & $\begin{array}{l}\text { Britton, 2013; Diedrich, } \\
\text { 2001; Dunlop, } 2006\end{array}$ \\
\hline Team as a system & $\begin{array}{l}\text { A team is formed of an interconnecting network of individuals. } \\
\text { This complex whole is the focus of the team coaching (rather } \\
\text { than the individuals within it) }\end{array}$ & $\begin{array}{l}\text { Team development } \\
\text { (Kozlowski \& Ilgen, 2006) }\end{array}$ & $\begin{array}{l}\text { Dasen, 2015; Diedrich, 2001; } \\
\text { Hawkins, } 2011 .\end{array}$ \\
\hline $\begin{array}{l}\text { Advanced coaching } \\
\text { skills }\end{array}$ & $\begin{array}{l}\text { Team coaching required advanced coaching skills due to the } \\
\text { complexity of coaching a group of individuals at the same time. } \\
\text { Includes simultaneously understanding multiple perspectives; } \\
\text { observe and interpret interactions; understanding of team }\end{array}$ & & \\
\hline
\end{tabular}


TEAM COACHING

facilitation techniques; ability to build trust to enable effective

openness and sharing between team members.

Coaching techniques Application of coaching techniques to achieve team goals and

improve team performance. Includes effective questioning and

abstaining from providing guidance or instruction.

Longer-term Team coaching is usually provided over a relatively longer-term 
TEAM COACHING

Table 4

\section{Classification of team learning and development interventions}

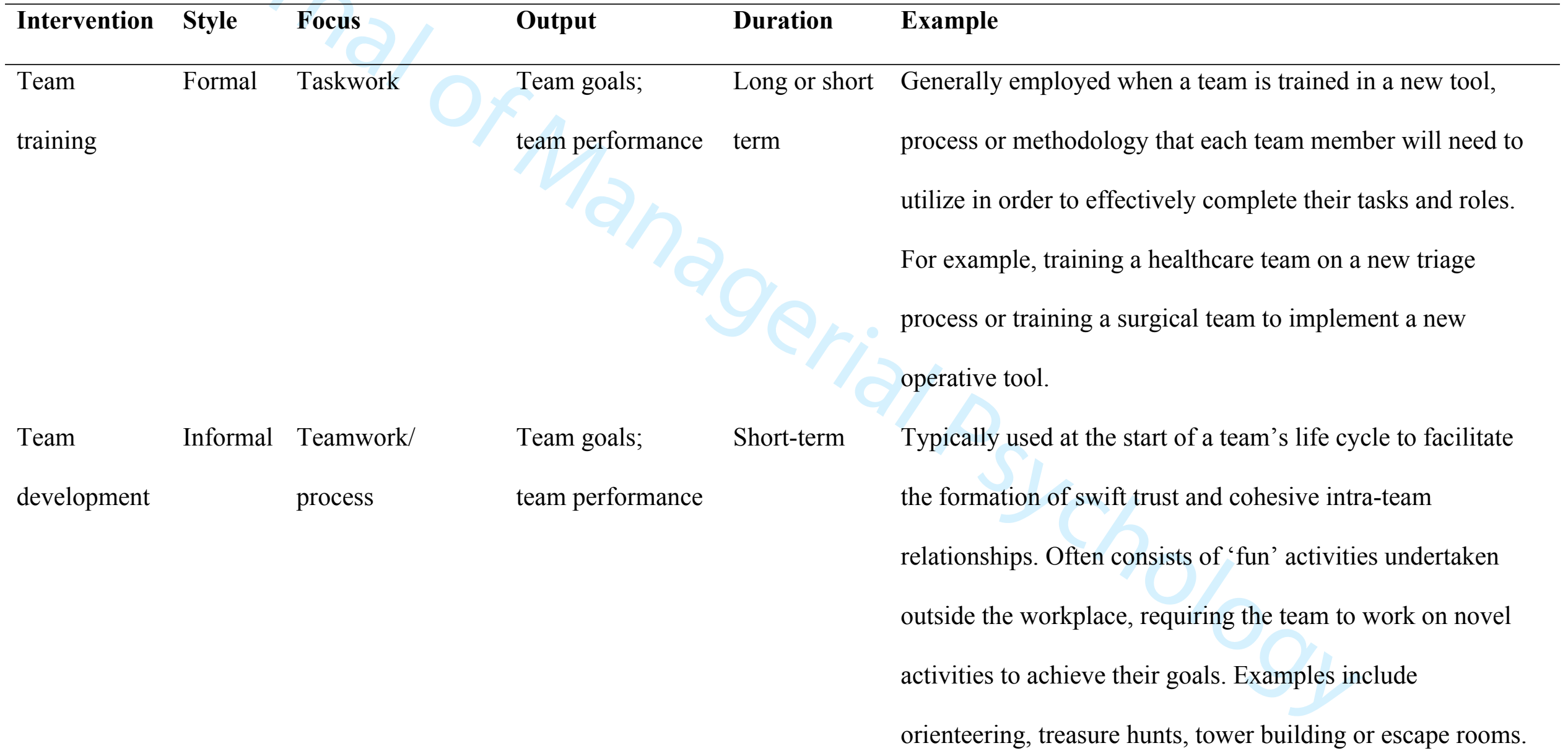




\section{TEAM COACHING}

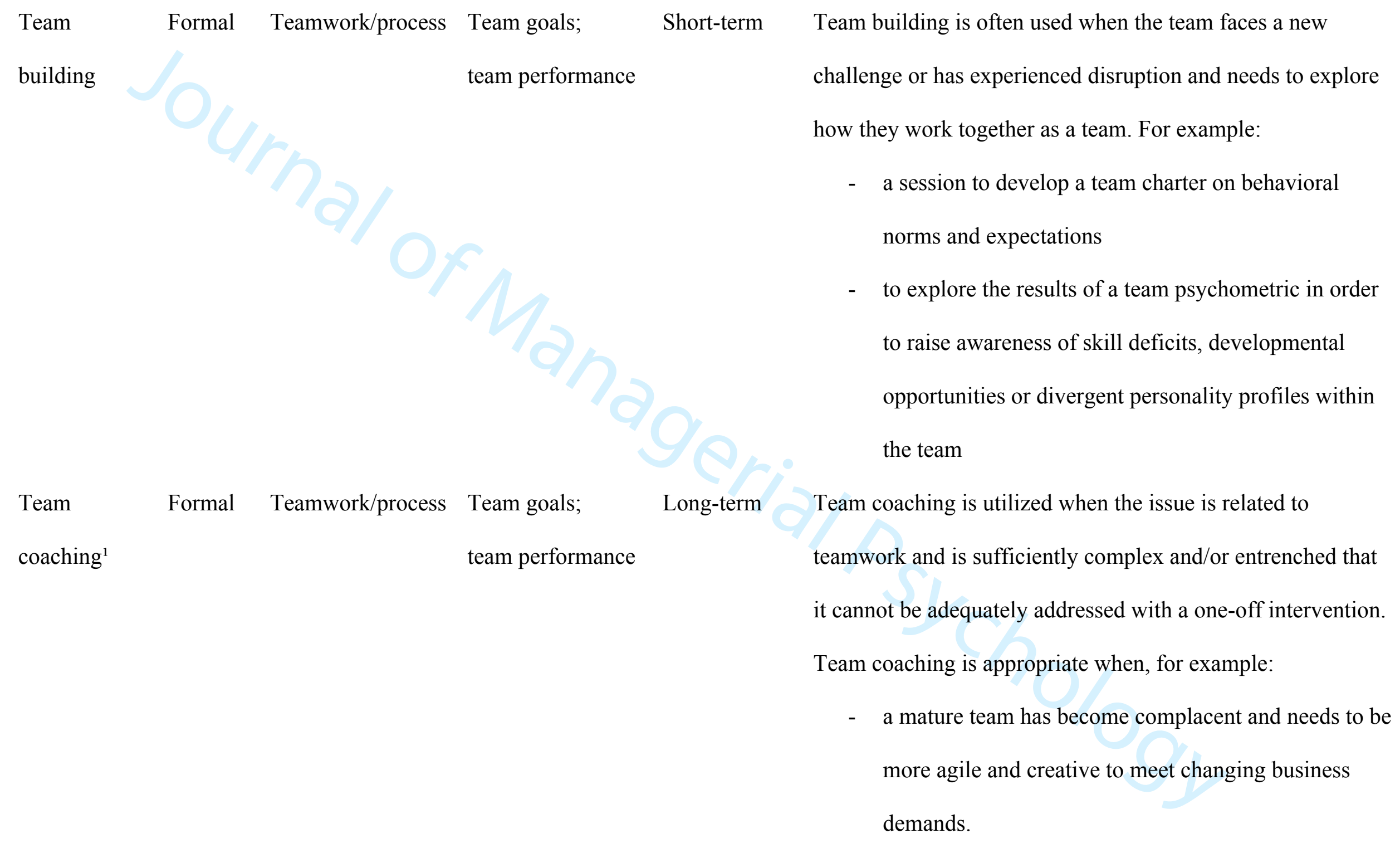




\section{TEAM COACHING}

- a team comprises of two overly dominant team members who stifle team discussions and undermine junior colleagues.

- a consistently poor-performing team that is unwilling to address the true causes of its problems and explore why it needs to change.

${ }^{1}$ The key differentiator between team building and team coaching is that outputs are achieved via the application of coaching techniques in team coaching. 


\section{TEAM COACHING}

\section{FIGURES}

\section{Figure 1}

\section{Hierarchical structure to themes from the team coaching definition literature}

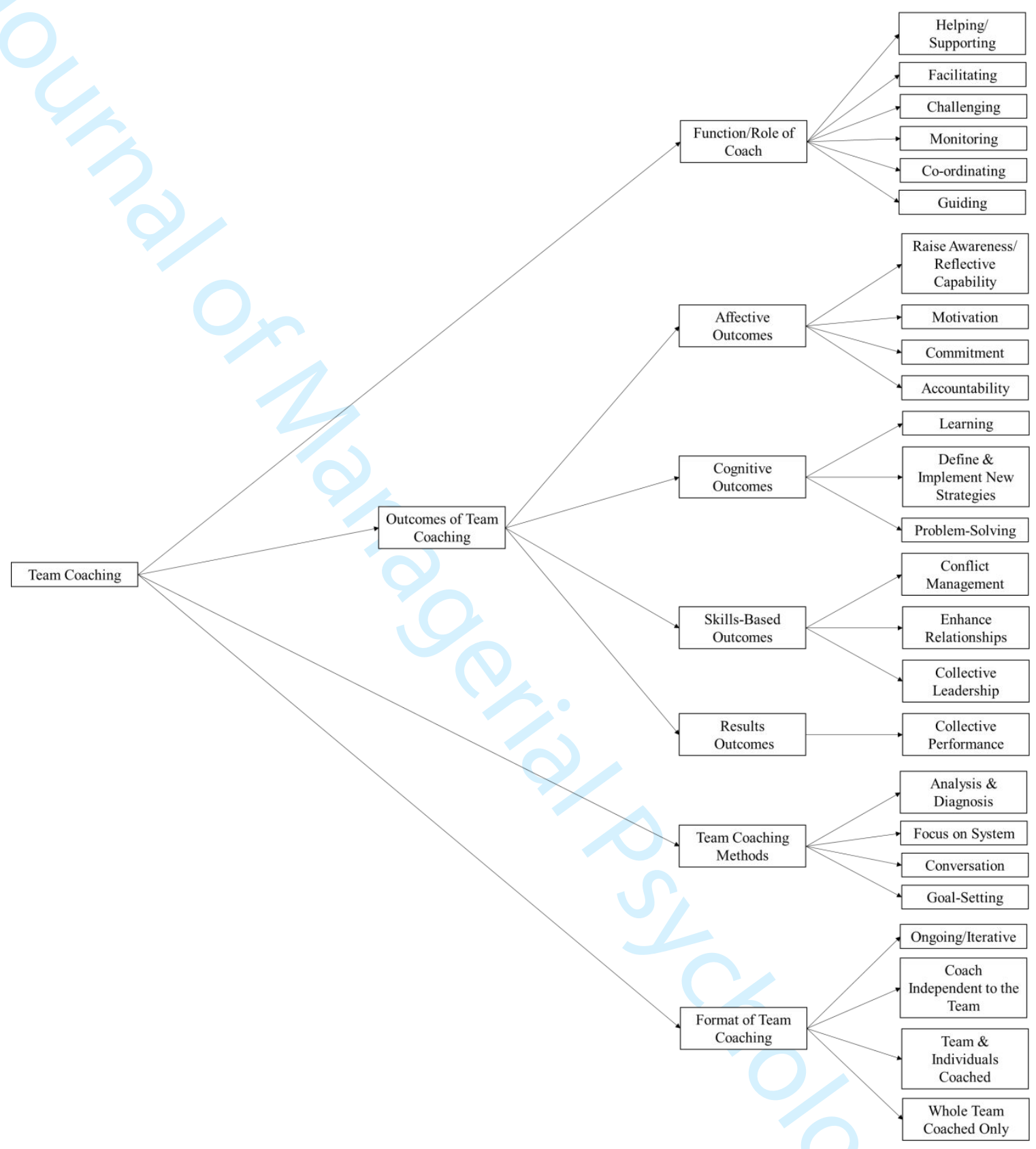

